Original article

Section: Food Technology

\title{
Fractional Factorial Design and Desirability Function-Based Approach in Spice Paprika Processing Technology to Improve Extractable Colour Stability
}

\author{
Arnold Koncsek $^{1 *}{ }^{\oplus}$, Lajos Szokol $^{1}$, Vivien Krizsa ${ }^{1}$, Hussein G. Daood ${ }^{2}$, \\ Lajos Helyes $^{2}{ }^{\circledR}$, Antal Véha ${ }^{3}$, Balázs P. Szabó ${ }^{3}$ () \\ ${ }^{1}$ Rubin Spice Paprika Processing Szeged Ltd., 173. Szerb Str., Szeged-Szöreg H-6771, Hungary \\ ${ }^{2}$ Horticultural Science Department, Hungarian University of Agriculture and Life Sciences, \\ 1 Páter Károly Str., Gödöllö H-2100, Hungary \\ ${ }^{3}$ University of Szeged, Faculty of Engineering, 5-7 Moszkvai Av., Szeged H-6725, Hungary
}

Key words: spice-paprika, extractable colour, experimental design, accelerated shelf-life test

The storage-stability of extractable colour in paprika powder is strongly influenced by the processing steps. The purpose of this research work was to decrease the degradation rate of extractable colour of paprika powders to 3-4 ASTA units/month and increase the shelf-life. Fractional factorial experimental design and desirability function-based approach was applied to moderate the adverse effect of the key-importance processing steps on colour agent content. Photochemical-accelerated shelf-life test was used for the empirically-based quality improvement. Post-harvest ripening, drying, sorting (seed content), milling and additives (paprika seed oil, tocopherol extract) were identified as important for the degradation rate of extractable colour. The colour stability was very sensitive to the milling and drying intensity, while proper setup of other processing steps compensated the adverse effect of drying and milling parameters. The supplementation with cold-pressed spice paprika seed oil was demonstrated as a natural way of colour stabilization. At the highest desirability value (0.986) the rate constant of accelerated colour stability test $(\mathrm{k})$ and shelf-life time $\left(\theta_{\mathrm{S}[100 \mathrm{ASTA}}\right)$ were -0.494 ASTA units/day and 2326 days, respectively. Alternative factor level settings enabled taking into account processing-tradition and efficiency expectation. In these cases, desirability values and the predicted shelf-life were $0.5-0.8$ and $712-918$ days, respectively. Validation study showed that the real observed rate constant and shelf-life values met the predicted values and their $95 \%$ confidence interval.

\section{INTRODUCTON}

The Hungarian red spice paprika (Capsicum annuum L.) powder is a highly appreciated product by consumers, professional chefs and food industry for its traditions and unique characteristics as spice. Red paprika was brought to Hungary at the end of 1500's [Moór \& Somogyi, 2017]. Growers and researchers have bred paprika cultivars that were most suitable for the local agricultural conditions and for the production of unique quality ground paprika. Empirically-based processing tradition has been developed by several generations of growers keeping in mind the gentle-handling of the raw material and developing the characteristics of milled paprika. The red spice paprika has become one of the most profitable agricultural products in Hungary after 1880 [Obermayer, 1934].

Spice paprika contains several valuable phytochemicals such as water- and fat-soluble antioxidants: phenolic compounds, capsaicinoids and carotenoids [Martí et al., 2011]. Epidemiological data have indicated possible roles of these phytochemicals in the prevention of numerous chronic diseases, including certain types of cancer, cardiovascular disease, stroke, and atherosclerosis [Chopan \& Littenberg, 2017; Hamed et al., 2019; Spiller et al., 2008].

During maturation, the fruit undergoes visual colour transformation due to the biosynthesis of carotenoids and the transformation of chloroplasts to chromoplasts [Martí et al., 2009]. The deep red colour of ripe pepper fruits is due to the high content of fat-soluble carotenoid-type pigment [Márkus et al., 1999]. More than 50 carotenoid-type compounds were identified in red pepper, mainly esterified with fatty acids in a form of mono- and di-esters [Daood et al., 2006; Giuffrida et al., 2013; Márkus et al., 1999]. Carotenoids are fairly stable in their natural environment, but become sensitive to light, temperature, enzymes, metals or oxygen as the structure of pod tissue and cells injures during post-harvest handling and processing [Perez-Galvez et al., 2009; Schieber \& Carle, 2005]. The colour stability of spice paprika was substantially influenced by the degree of carotenoid-esterification, the level of antioxidants, such as ascorbic acid and tocopherols, formed during the ripening of pods [Daood et al., 2006; Márkus et al., 1999].

\footnotetext{
* Corresponding Author:

Tel.: 00-36-70-3335964;

E-mail: labor@rubinpaprika.hu (A. Koncsek)
} 
In the industrial and commercial practice, the extractable colour determined by the American Spice Trade Association (ASTA) method and expressed as ASTA colour value is indicative of quality of spice paprika powder, which is easy to measure (photometric method) and representative throughout the product shelf-life [ASTA, 1997]. The degradation rate of extractable colour is a suitable indicator for evaluating the effect of processing factors.

The industrial mass production has pushed the experience of traditional gentle processing into the background. Long-term experience of present research group showed that the degradation rate of extractable colour is 6-8 ASTA units/month with the generally applied industrial processing of spice paprika. This means that the shelf-life is 360-400 days, calculated for 100 ASTA units of final colour value, as the minimum requirement of $1^{\text {st }}$ grade paprika powder [ISO 7540:2006].

Numerous research works are available in literature focusing on the optimization of a selected single processing step [Daood et al., 1996, 2006; Hamed et al., 2019; Ibrahim et al., 1997; İnanç et al., 2010; Karam et al., 2016; Koncsek et al., 2019; Márkus et al., 1999; Singh \& Goswami, 1999]. However, the processing of spice paprika is a complex technology. Simultaneous and comprehensive optimization of industrial operations was required, taking into consideration the sensitivity of the valuable components in spice paprika. The objective of this research work was to decrease the degradation rate of extractable colour to 3-4 ASTA units/month in red spice paprika powders and increase the shelf-life. During the fresh spice paprika processing, the improper post-harvest ripening, heat stress (drying and milling) and mechanical stress (surface increase due to milling) enhance the process of the colour degradation [Daood et al., 2006; Márkus et al., 1999]. The research team assumed that the adverse effects of key-importance processing steps on colour agent content can be moderated with the help of fractional factorial experimental design and desirability function-based approach. Three varieties of cultivated fresh spice paprika were involved in the investigations. Variety, post-harvest ripening methods, intensity of drying and milling, sorting (seed content), and using of additives (paprika seed oil and tocopherol extract) were simultaneously and comprehensively investigated.

\section{MATERIALS AND METHODS}

\section{Raw materials}

The spice paprika varieties were cultivated on the fields of the Gorzsa Agricultural PLC (Hodmezovasarhely, Hungary), within the traditional Szegedi Spice Paprika production area. In the present study, varieties Meteorit, Fesztival and Mihalyteleki were used. The ripe (deep red) pods were hand-harvested in the 2017 and 2018 season.

\section{Processing and experimental design}

Seven processing variables (variety, post-harvest ripening, drying, sorting, milling, paprika seed oil and tocopherol extract as additives), as quantitative and qualitative factors, were investigated in the fractional factorial design at 3 levels, thus the experiment consisted of 81 runs (Table 1). The variables were decided earlier in preliminary studies at Rubin
Spice Paprika Processing Ltd. (Szeged, Hungary). The pilot factory technology is shown in Figure 1.

According to the traditional Hungarian processing principles, the hand-harvested fresh pods were stored for 1.5 weeks to reach post-harvest technological ripeness. The thermal dehydration was done in an industrial drying unit (Hans Binder HGI/18F, Marzling, Germany, 1986), with washing equipment, manual sorting, chopper and drying tunnel.

The seeds were separated with the help of an industrial sorting sieving machine (Index Ltd., Kalocsa, Hungary, 1995). A screw oil press machine (OKB-1 models, $150 \mathrm{~kg} / \mathrm{h}$ capacity, 7.5 kW power, Seed-Imex Ltd., Kisbér, Hungary) was used for the cold-pressing of spice paprika seed oil. The oil was cleaned through a $1.0 \mathrm{~mm}$ screen and then by gravitational sedimentation.

The dry spice paprika lots were processed in a milling system (Constructed by Zöldacél kft., Szeged, Hungary; id. no.: 001/2017,35 kW) including a pin mill followed by an in-line sieve that allowed fine particles $(<450 \mu \mathrm{m})$ in a mixer. The coarse particles were sent back from the screen to the grinder. The paprika powders were mechanically homogenized with additives (tocopherol and/or cold pressed seed oil) in the mixer.

The processing was repeated with the 2018 season's crop in order to validate the optimized processing parameters.

\section{Accelerated colour stability test}

The colour stability of paprika powder samples was analysed by the photochemical-accelerated method as described previously by Koncsek et al. [2016]. Samples of $15 \mathrm{~g}$ for each (in triplicate) were spread in Petri dishes to maintain the equal laying thickness (approx. $5 \mathrm{~mm}$ ) and exposed to illumination of 6,000 lux in a light chamber. The samples were mixed daily. The chamber $(420 \times 1,040 \times 500 \mathrm{~mm})$ was equipped with two fluorescent lamps (Oshram Biolux T8 daylight, $30 \mathrm{~W}$, colour temperature: $6,500 \mathrm{~K}$ ) and light intensity adjusting unit. The light intensity was monitored by a digital Voltcraft MS-1300 light meter (Conrad, Berlin, Germany).

The extractable colour of paprika samples was measured according to the ASTA 20.1 method [ASTA, 1997] at the beginning of the experiment and after 7, 14 and 28 days, and expressed as ASTA colour value which was calculated according to the following formula:

$$
\text { ASTA colour value }=\frac{\text { Absorbance of sample } \times 16.4 \times \text { Factor }}{\text { Weight of sample }(g)}
$$

where: factor is 0.315 per absorbance of the standard colour solution.

\section{Data analysis}

The extractable colour loss was evaluated with chemical kinetics principles. The photochemical-accelerated degradation followed apparent zero order reaction model [Koncsek et al., 2016]:

$$
[C]=-k \times t+\left[C_{0}\right]
$$

where: $\mathrm{k}$ is the apparent reaction rate constant, $\mathrm{C}$ is the extractable colour (ASTA colour value), and $\mathrm{C}_{0}$ is the initial extractable colour (initial ASTA colour value). 
TABLE 1. Variables of spice paprika processing experiment design (fractional factorial design at 3 levels).

\begin{tabular}{|c|c|c|c|}
\hline Factors & Setup & Coded level & Details \\
\hline \multirow{3}{*}{ Variety $\left(\mathrm{x}_{1}\right)$} & Meteorit & -1 & \\
\hline & Fesztival & 0 & \\
\hline & Mihalyteleki & 1 & \\
\hline \multirow{3}{*}{ Post-harvest ripening $\left(\mathrm{x}_{2}\right)$} & Outdoors, spread & -1 & $200 \mathrm{~mm}$ layer \\
\hline & Outdoors, heap & 0 & $600 \mathrm{~mm}$ heap \\
\hline & Protected area & 1 & $300 \mathrm{~mm}$ layer \\
\hline \multirow{3}{*}{ Drying $\left(\mathrm{x}_{3}\right)$} & Slow, $330 \mathrm{~kg} / \mathrm{h}$ & -1 & $\begin{array}{c}\text { Initial zone: } 69-76^{\circ} \mathrm{C} \\
\text { Middle zone: } 43-55^{\circ} \mathrm{C} \\
\text { Final zone: } 25-30^{\circ} \mathrm{C}\end{array}$ \\
\hline & Moderate, $416 \mathrm{~kg} / \mathrm{h}$ & 0 & $\begin{array}{c}\text { Initial zone: } 75-85^{\circ} \mathrm{C} \\
\text { Middle zone: } 55-65^{\circ} \mathrm{C} \\
\text { Final zone: } 29-36^{\circ} \mathrm{C}\end{array}$ \\
\hline & Intensive, $500 \mathrm{~kg} / \mathrm{h}$ & 1 & $\begin{array}{c}\text { Initial zone: } 95-105^{\circ} \mathrm{C} \\
\text { Middle zone: } 72-80^{\circ} \mathrm{C} \\
\text { Final zone: } 35-40^{\circ} \mathrm{C} \\
\end{array}$ \\
\hline \multirow{3}{*}{ Seed content (sorting) $\left(\mathrm{x}_{4}\right)$} & $3 \%$ & -1 & Without seeds: $\sim 3 \%$ \\
\hline & $10.5 \%$ & 0 & Medium seed content: $9-12 \%$ \\
\hline & $20.5 \%$ & 1 & Total seed content: $19-22 \%$ \\
\hline \multirow{3}{*}{ Milling $\left(\mathrm{x}_{5}\right)$} & Slow, $110 \mathrm{~kg} / \mathrm{h}$ & -1 & $\begin{array}{l}\text { Stationary pin number: } 63 \\
\text { Rotating pins: } 86\end{array}$ \\
\hline & Moderate, $140 \mathrm{~kg} / \mathrm{h}$ & 0 & $\begin{array}{l}\text { Stationary pin number: } 84 \\
\text { Rotating pins: } 115\end{array}$ \\
\hline & Intensive, $170 \mathrm{~kg} / \mathrm{h}$ & 1 & $\begin{array}{l}\text { Stationary pin number: } 105 \\
\text { Rotating pins: } 145\end{array}$ \\
\hline \multirow{3}{*}{ Paprika seed oil $\left(\mathrm{x}_{6}\right)$} & $0 \%$ & -1 & \\
\hline & $3 \%$ & 0 & \\
\hline & $6 \%$ & 1 & \\
\hline \multirow{3}{*}{ Tocopherol additive $\left(\mathrm{x}_{7}\right)$} & $0 \%$ & -1 & \\
\hline & $0.1 \%$ & 0 & \\
\hline & $0.2 \%$ & 1 & \\
\hline
\end{tabular}

Half-life time $\left(\mathrm{t}_{1 / 2}\right)$ is described by Eq. 3:

$$
t_{1 / 2}=\frac{\left[C_{0}\right]}{2 k}
$$

The relationship between the illumination level and reaction time was expressed by a power function and the shelf-life to a specified ASTA colour value was estimated with empirically developed formula [Koncsek et al., 2016]:

$$
\theta_{S[100 A S T A]}=\frac{[C]-\left[C_{0}\right]}{-k \times I^{b}}
$$

where: $\theta_{\mathrm{S}[100 \mathrm{ASTA}]}$ is predicted shelf-life to 100 ASTA colour value, $\mathrm{I}$ is illumination level, and $\mathrm{b}$ is the slope of shelf-life plot functions $(-0.286)$. The bias of model was taken into consideration in the calculation.

Microsoft Excel (Microsoft, Redmond, WA, USA) and Statistica 8.0 (StatSoft Inc., Tulsa, OK, USA, 2007) softwares were used for the fractional factorial design analysis and kinetics computations. Shapiro-Wilk test was used for checking the normal distribution. Box-Cox transformation was used for stabilizing variance and improving the data analysis. In all analyses, a 5\% significance level was considered.

Desirability function-based approach was used for optimizing processing parameters. This approach converts an optimization problem with multiple quality characteristics into a single dimensionless response optimization problem. Response variables $\left(\mathrm{Y}_{\mathrm{i}}\right)$ are transformed into desirability values $\mathrm{d}_{\mathrm{i}}\left(0 \leq \mathrm{d}_{\mathrm{i}} \leq 1\right)$. If the product characteristic is in an unacceptable range, the desirability value (D) is 0 and if the product characteristic is at the optimum, the value is 1 [Pal \& Gauri, 2018]. The equations describe this approach:

$$
\begin{aligned}
& d_{i}= \begin{cases}0 & Y_{i}<\text { Low }_{i} \\
\left(\frac{Y_{i}-\text { Low }_{i}}{\text { High }_{i}-\text { Low }_{i}}\right)^{w} & \text { Low }_{i}<Y_{i}<H i g h_{i} \\
1 & Y_{i}>H_{i g h}\end{cases} \\
& d_{i}= \begin{cases}1 & Y_{i}<\operatorname{Low}_{i} \\
\left(\frac{Y_{i}-\text { Low }_{i}}{\text { Hgig }_{i}-\text { Low }_{i}}\right)^{w} & \text { Low }_{i}<Y_{i}<H i g h_{i} \\
0 & Y_{i}>H i g h_{i}\end{cases} \\
& D=\left(\prod_{i=1}^{n} d_{i}^{r_{i}}\right)^{1 / \Sigma r_{i}}
\end{aligned}
$$




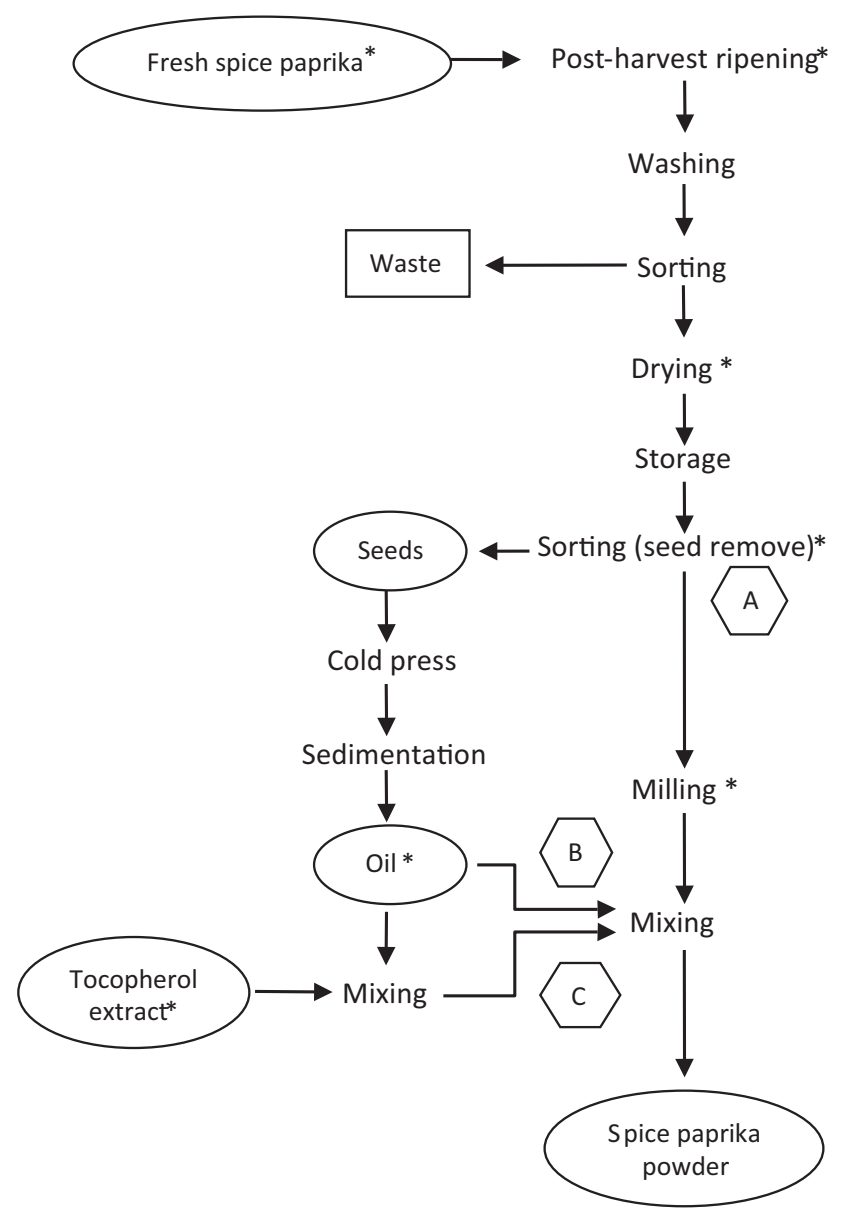

FIGURE 1. Flow chart of spice paprika processing technology in the pilot factory ("investigated factors, "A" - Processing without additives, "B" - Processing combined with cold pressed spice paprika seeds oil, "C" - Processing combined with tocopherol additive).

\section{RESULTS AND DISCUSSION}

The initial extractable colour $\left(\mathrm{C}_{0}\right)$ of paprika powder samples is shown in Figure 2 as ASTA colour values. The powder of Meteorit variety without seed sorting had the lowest colour values (145-157 ASTA units) that showed no significant increase in the protected storage condition. For this variety, the outdoors storage and semi-protected arrangement (in $600 \mathrm{~mm}$ heap) means satisfactory conditions to reach technological ripeness. The extractable colour values of Fesztival and Mihalyteleki paprika were 162 and 194 ASTA units in the protected storage area, while colour values were 10-18 ASTA units lower in the unprotected areas. In the case of Fesztival and Mihalyteleki paprika, the "de novo" extractable colour accumulation was remarkably aided by protected storage. The protected condition was set up in well-ventilated and dark warehouse. Thin layer arrangement of batches increased the adverse effects of environment (light, temperature fluctuation) on extractable colour synthesis. As shown by other authors, sun-drying (exposure to light) caused a remarkable decrease in the contents of carotenoids and antioxidants [Daood et al., 2014; Topuz \& Ozdemir, 2003]. The importance of balanced and moderate storage temperature has been confirmed by Márkus et al. [1999] and Acedo [2010],

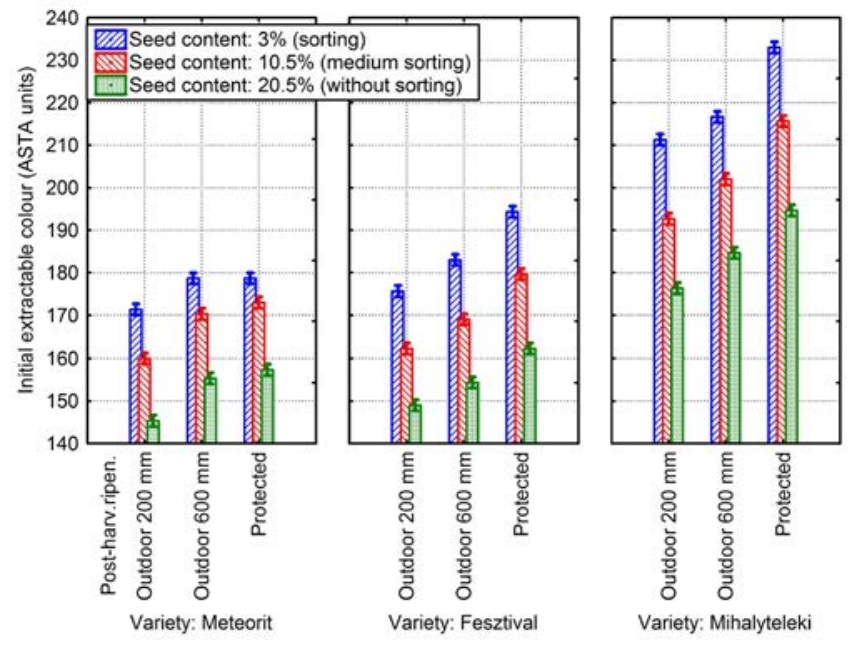

FIGURE 2. Effect of variety, post-harvest ripening methods and sorting (seed content) on the initial extractable colour values (ASTA units) of spice paprika powder.

because storage at 20 to $23^{\circ} \mathrm{C}$ improved the development of red colour in partially ripe paprika. In accordance with a study of Pola et al. [2020], the present results suggested that different Capsicum varieties have a diversity of post ripening demands (time, light or dark and temperature) to reach the best carotenoid accumulation.

The seeds do not contain carotenoids, thus total-seed-containing paprika powders had lower initial extractable colour, than sorted samples (Figure 2). Depending on post-ripening procedure, the available highest colour values were 171-178 ASTA units in Meteorit, 175-194 ASTA units in Fesztival and 211-233 ASTA units in Mihalyteleki paprika, when the seed content was only around $3 \%$. The decrease of content or removal of seeds gave better initial quality of paprika powder and its effect on the colour stability was investigated with the help of kinetic parameters.

The pigment degradation kinetic parameters (initial extractable colour, $\mathrm{C}_{0}$ and rate constant, $\mathrm{k}$ ) and the estimated shelf-life time $\left(\theta_{\mathrm{S}[100 \mathrm{ASTA})}\right)$ were calculated for 81 runs (factor combinations). The outcome of simple linear regression, fitting the regression line $\left(\mathrm{R}^{2}\right.$, adjusted $\left.\mathrm{R}^{2}>0.9\right)$, results of F test $(p<0.05)$ and residual analysis, confirmed the zero-order kinetic model. The estimated shelf-life was calculated for 100 ASTA units of final colour value, as the minimum requirement of $1^{\text {st }}$ grade paprika powder [ISO 7540:2006]. The rate constant and the estimated shelf-life of accelerated colour stability test showed wide range differences $\left(\mathrm{k}=-3.208-0.453\right.$ ASTA units/day, $\theta_{\mathrm{S}[100 \mathrm{ASTA}]}=260-2240$ days, all data is not shown), indicating the importance of processing factor setups on colour stability.

Figure 3 and Figure 4 shows the normal probability plot of the standardized effects and Pareto plot to evaluate the significance of each factor and its interactions on $\mathrm{k}$ and $\theta_{\mathrm{S}[100 \mathrm{ASTA}]}$. The standardized effects are ranked, and then plotted against the expected normal probability. The effects that are negligible are normally distributed, with mean zero and variance $\sigma 2$ and tend to fall along a straight line [Montgomery, 2013]. The significant real effects are separated in the upper 

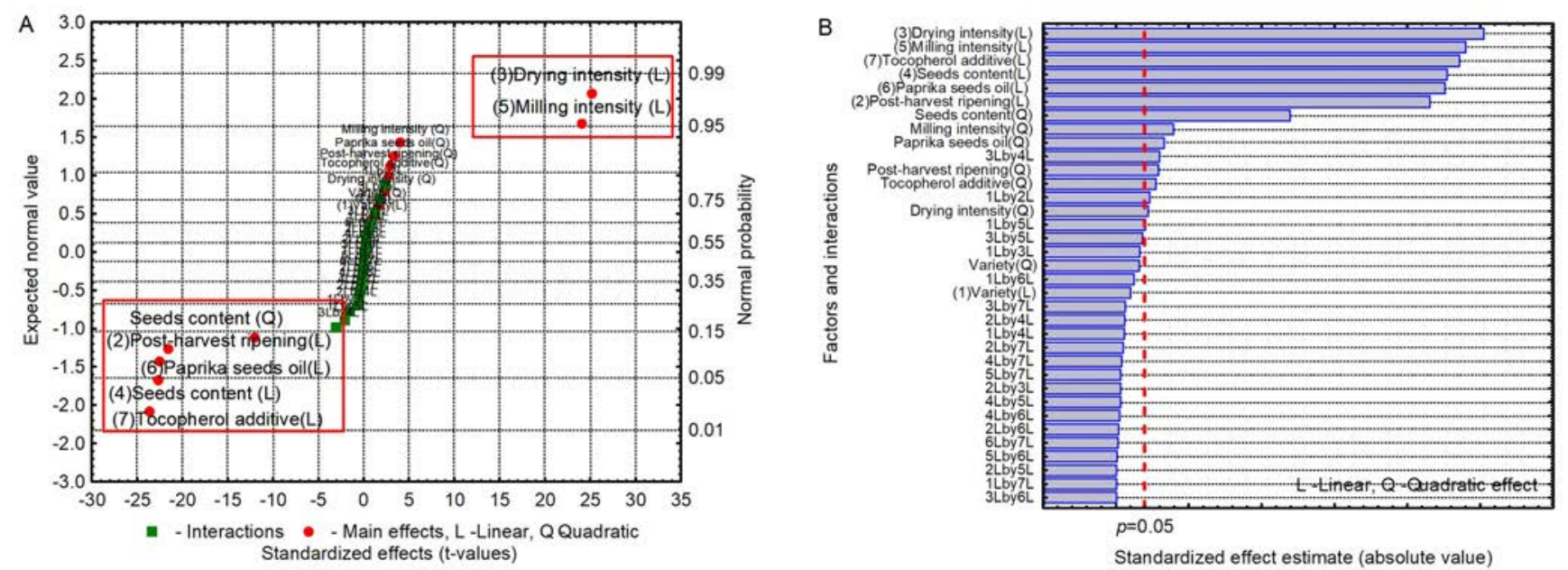

FIGURE 3. Normal probability plot (A) and Pareto chart of the standardized effects (B) on the (transformed) degradation rate constant (k) of extractable colour in spice paprika powder. (Red frames indicate the processing variables that were identified as important for degradation rate constant).
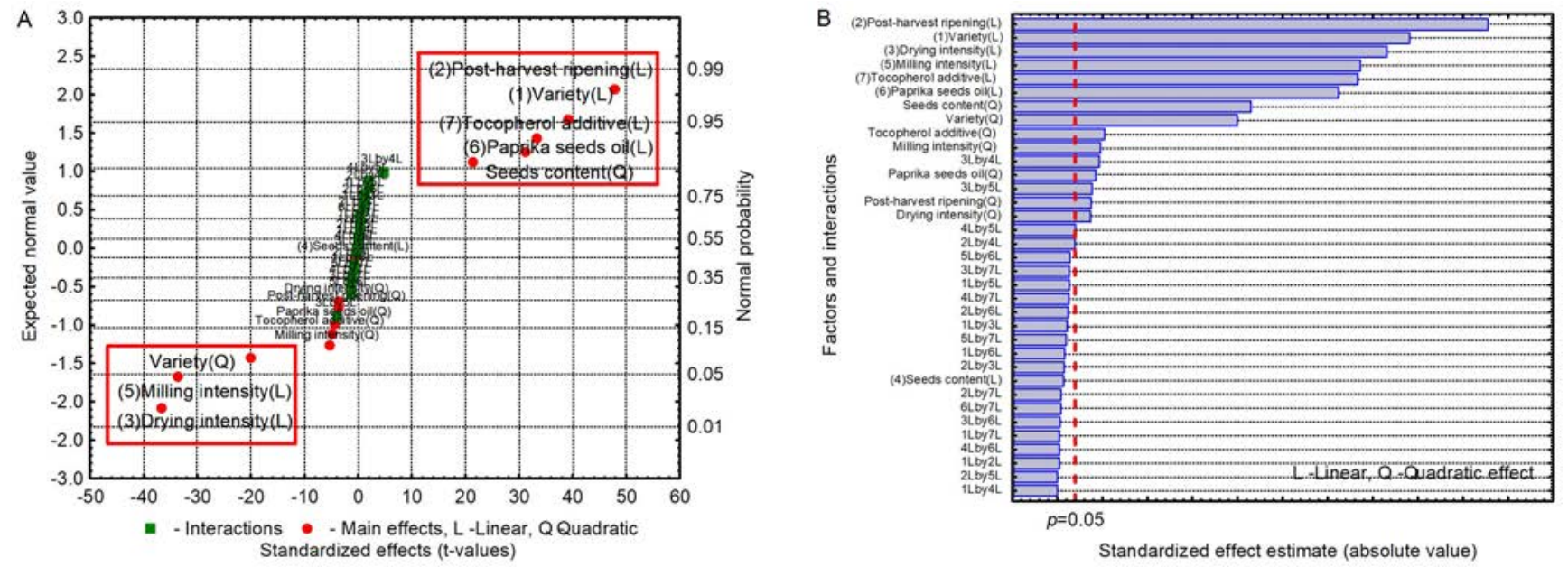

FIGURE 4. Normal probability plot (A) and Pareto chart of the standardized effects (B) on estimated shelf-life time $\left(\theta_{\text {SI100ASTA }}\right)$ of spice paprika powder. (Red frames indicate the processing variables that were identified as important for shelf-life).

right-hand and lower left-hand corner of the plots (Figure $3 \mathrm{~A}$ and Figure 4A).

All processing variables, as main effects, were identified as important for rate constant. Positive position of variables (drying and milling) means that a change from a low to a high level increased the degradation rate of extractable colour (Figure 3A). The Pareto chart with high absolute standardized effects of these factors indicated their remarkable influence on the degradation rate of extractable colour (Figure 3B). High factor levels of other processing steps (e.g. seed content, supplementation with spice paprika seed oil or tocopherol) suggested the compensation opportunity against the adverse effect of drying and milling parameters.

Besides processing factors, the variety was significant for the shelf-life response variable. Drying and milling intensity negatively affected the shelf-life (Figure 4A). This preliminary analysis indicated that the proper setup of parameters contributes to the extended stability of products. The plot shows that the colour stability is very sensitive to the milling and drying intensity if the parameters were at high levels.
Variety factor appeared in positive and negative position in the normal probability plot as linear and quadratic variables of model. This suggested that this qualitative variable represents complex properties. The shelf-life estimation formula indicated that the calculated time values depended on the initial extractable colour of paprika powders. This clearly appeared in the Pareto chart (Figure 4B), since standardized effects of variety and post-ripening control factors were the largest among the other factors. Earlier studies have found intensive esterification of capsanthin, capsorubin and other xanthophylls with fatty acids during the post-harvest ripening [Márkus et al., 1999]. These conversions promoted the stabilization of carotenoids during the further processing and storage of spice paprika, providing stability against thermo, photo and enzymatic oxidation reactions [Arimboor et al., 2015].

The effect of processing variables on rate constant of accelerated colour stability test is shown graphically in Figure 5. These marginal means plots averaged the means across the settings and combinations of settings of the factors. 

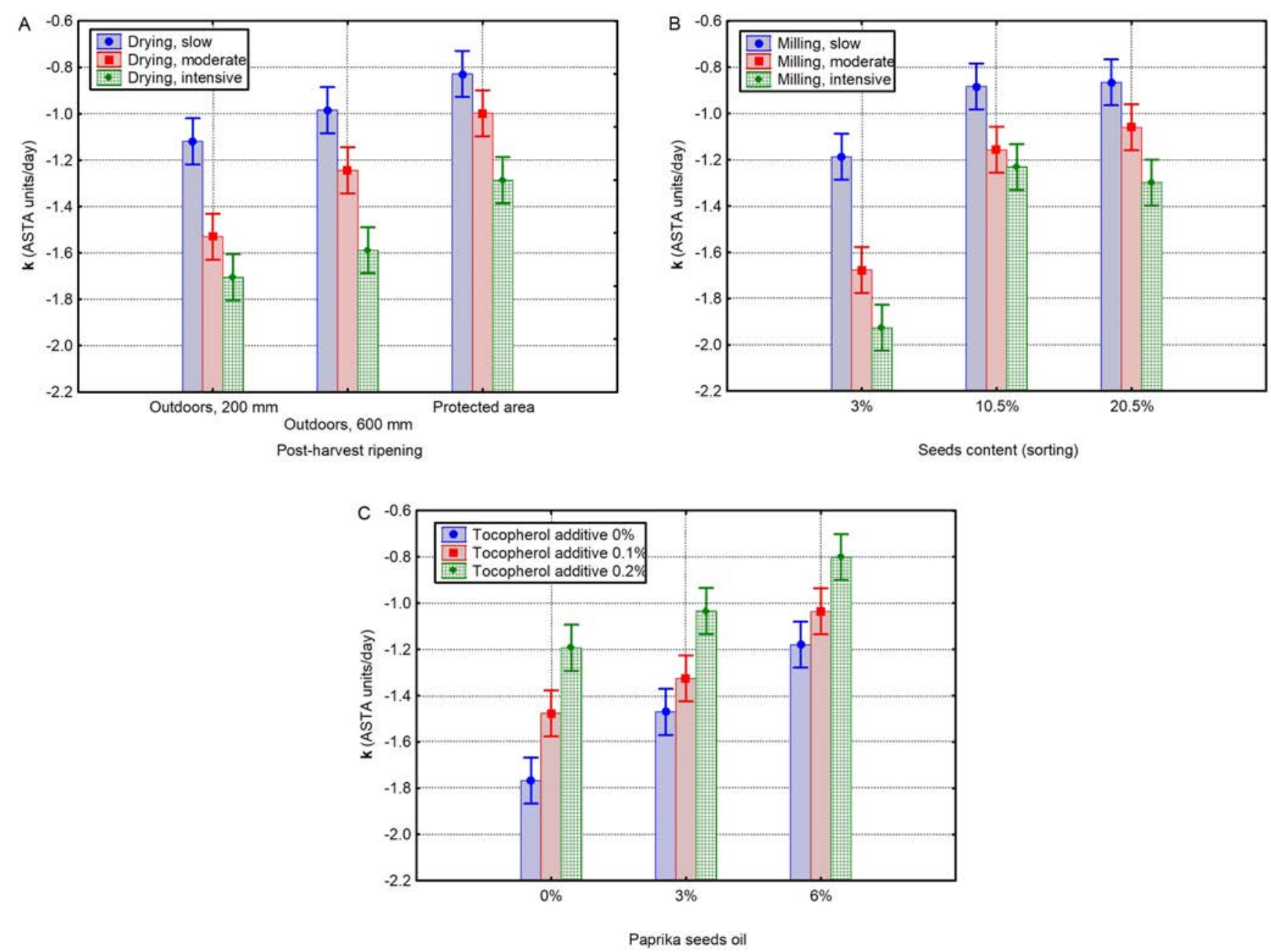

FIGURE 5. The effect of processing variables on the degradation rate constant $(\mathrm{k})$ of extractable colour in spice paprika powder. Plot A - processing in drying factory, Plot $\mathrm{B}$ - processing in milling factory, Plot $\mathrm{C}$ - processing combined with additives.

The indicated confidence limits were computed based on the respective estimates of the standard errors.

Outdoors post-ripening is a generally applied method in the case of industrial volumes. Thin layer $(200 \mathrm{~mm})$ storage was not advised because remarkable damages were observed in pods and higher degradation rate of extractable colour with rate constants of -1.705 and -1.530 ASTA units/day for intensive and moderate dried samples, respectively (Figure 5A), indicating weaker colour stability in the final product. However, the slow drying significantly compensated the adverse effect of thin layer outdoors post-ripening $(\mathrm{k}=-1.119$ ASTA units/day). Storage in $600 \mathrm{~mm}$ heaps and protected area combined with moderate or slow drying intensity revealed significantly lower degradation rate of extractable colour (k ranged from -0.828 to -0.998 ASTA units/day). Postripening in $600 \mathrm{~mm}$ heaps protected the deep layers from the external conditions. Protected post-ripening was most advantageous on colour retention, and seemed to compensate the adverse effect of intensive drying. This method is less usable in industrial volumes because of remarkable place-demand, but useful in craft-like processing tradition. These findings were consistent with several previous studies. Ibrahim et al. [1997] have identified two stages in carotenoid content change during light-exposed and protected (in dark) natural drying of spice paprika. The first stage was a biosynthetic and the second was degradative with more adverse effect of light-exposure than darkness. The retention of phytochemicals (ascorbic acid and tocopherols), that play important role in carotenoid stability, has been found to be significantly worse in naturally dried paprika than in thermally-dried paprika [Daood et al., 1996, 2014].

Exposure of spice paprika to higher temperature (intensive drying) resulted in substantial deterioration of extractable colour during the accelerated storage-stability experiment (Figure 5A). The marginal means of rate constants were 1.5-1.6 and 1.1-1.3 times lower, as compared with slow drying and moderate drying, respectively. Many authors have reported the colour deterioration as proportional with the temperature and time of hot-air drying technology, which might be due to Maillard reactions and heat sensitivity of carotenoids and other antioxidants [Daood et al., 2006; Karam et al., 2016].

Reduction of the seed content to $3 \%$ accelerated the extractable colour degradation, especially with more intensive milling (Figure 5B). The marginal means of rate constants (-1.187 ASTA-units/day) were 1.3-1.4 times lower 

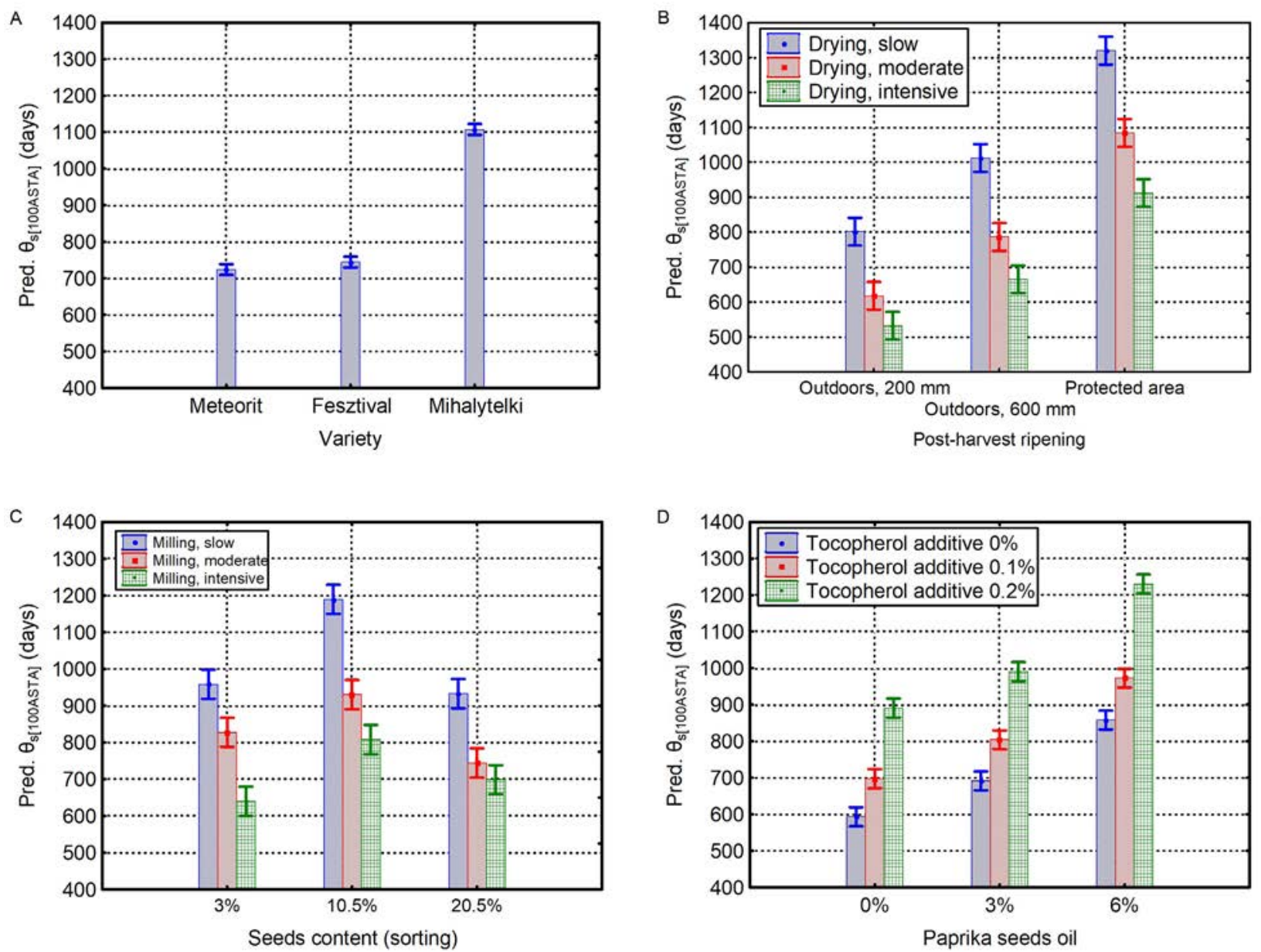

FIGURE 6. The effect of processing variables on estimated shelf-life time $\left(\theta_{\mathrm{S}[100 \mathrm{ASTA}}\right)$ of spice paprika powder. Plot A - variety, Plot B - processing in drying factory, Plot $\mathrm{C}$-processing in milling factory, Plot $\mathrm{D}$ - processing combined with additives.

in the slow- and moderate-intensity milled seed-less samples, than in their medium seed-content and non-sorted alternatives (-0.874 ASTA units/day). Studies have demonstrated that the oil and $\gamma$-tocopherol derived from seeds are essential elements in the carotenoid stability of paprika powder [Daood et al., 1996; Koncsek et al., 2016]. There were no significant differences between the effects of medium and total seed content on the rate constant. Omitting of sorting might be a reasonable decision to decrease degradation rate of extractable colour.

The slow and moderate milling intensity was found to be favourable, resulting in slower degradation rate than intensive milling (Figure 5A). Conventional grinding can rise the temperature over $90^{\circ} \mathrm{C}$ due to the friction-induced heat, causing important losses of aroma, nutrients and flavour components, as well as considerable quality degradation [Karam et al., 2016; Singh \& Goswani, 1999]. However, heat and mechanical forces played an important role in the quality of traditional spice paprika powders. During grinding, the heat enabled to release the oil from the seeds, which interacted with the pigment in the pericarp particles to produce intense red colour [Berke \& Shieh, 2001; Szegedi paprika, 2010].

The supplementation with cold-pressed spice paprika seed oil and tocopherol extract decreased the degradation rate of extractable colour of paprika powder (Figure $5 \mathrm{C}$ and Figure 5D). The spice paprika seed oil was less effective $(\mathrm{k}=-1.180-1.147$ ASTA units/day) than the combination of oil and tocopherol additive $(\mathrm{k}=-0.801-1.034$ ASTA units/day). However, at higher dose $(6 \%)$, the oil was close to the efficacy of the $0.2 \%$ tocopherol additive $(\mathrm{k}=-1.193$ ASTA units/day). The supplementation with oil is a natural way of quality stabilization using the original compounds of spice paprika. Earlier studies have shown successful application of high-oleic sunflower seed [Pérez-Gálvez et al., 2000], soybean oil [İnanç et al., 2010], $\delta$-tocopherol [Osuna-Garcia et al., 1997] and rosemary extract [Koncsek et al., 2019] as additives to moderate the carotenoid degradation in paprika powders or products. The principles of the processing technology, laid down in the related legislative regulations, restricted the presence of non-paprika origin components in the traditional Hungarian spice paprika powder marketed in retail.

The effects of processing variables on estimated shelf-life time $\left(\theta_{\mathrm{S}[100 \mathrm{ASTA}]}\right)$ are shown graphically in Figure 6 . The variety-effect plot shows that Mihalyteleki variety with the highest initial extractable colour (203 ASTA units) revealed the best marginal mean of estimated shelf-life time (1107 days). This can be attributed to the zero-order degradation kinetics 


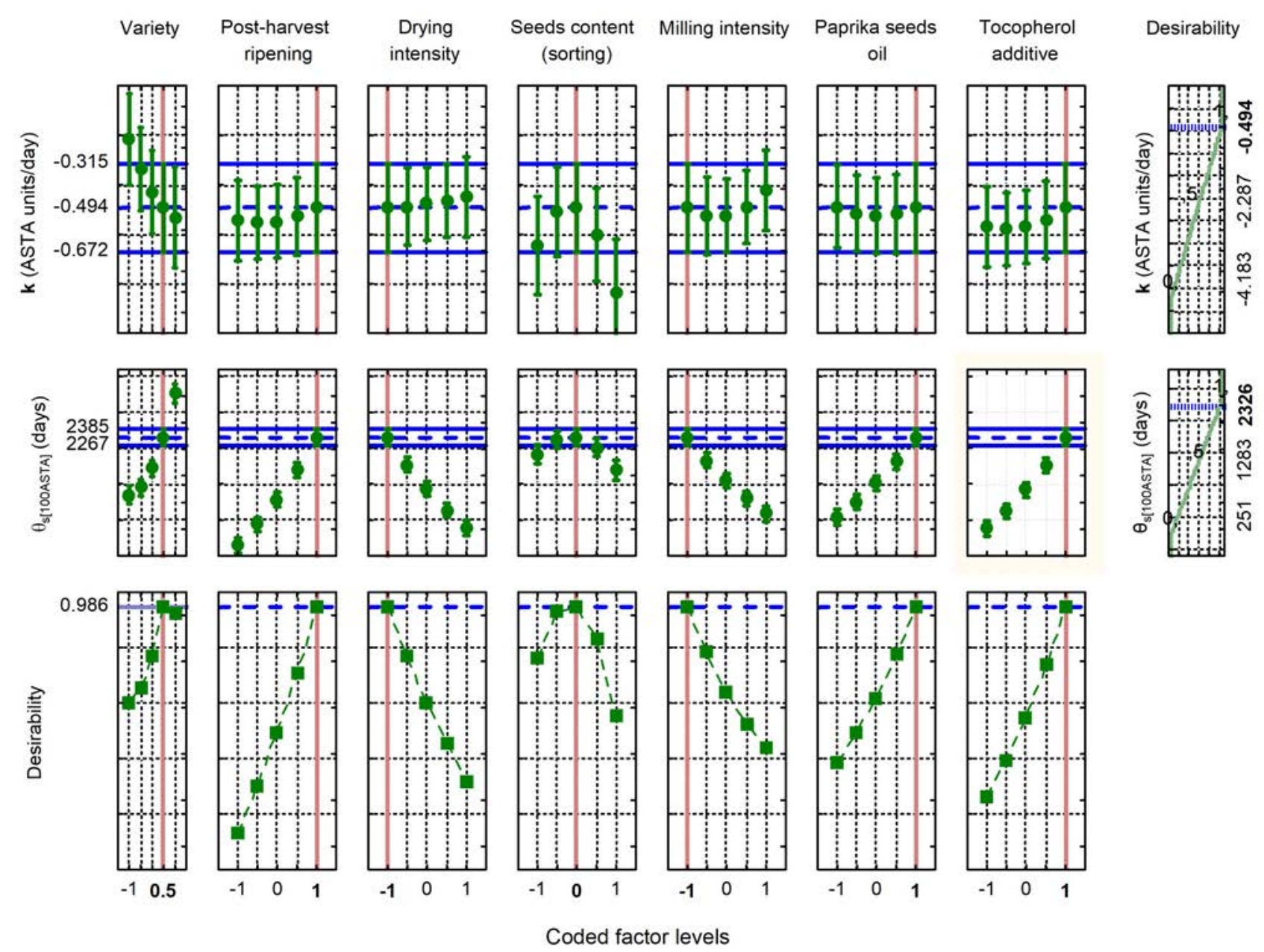

FIGURE 7. Desirability function-based approach for spice paprika processing at the highest desirability level. (Red vertical dashed lines - the best processing factor settings, blue horizontal dashed lines - the highest available shelf-life and lowest degradation rate constant, green points - shelf-life and degradation rate constant values, continous blue lines - 95\%-level confidence prediction).

of carotenoids, because in this model the degradation time depends on the initial concentration of the useful component [Koncsek et al., 2016; Peleg, 2017].

Both reduction of the seed content to $3 \%$ and omitting of seed sorting shortened the estimated shelf-life time (Figure 6C). As mentioned above, the seeds do not contain carotenoids and thus total-seed-containing paprika powders had a lower initial extractable colour value (164 \pm 16 ASTA units), compared to the medium-sorted samples. This lower initial extractable colour decreased the $\theta_{\mathrm{S}[100 \mathrm{ASTA}]}(698-937$ days). Higher initial ASTA colour values were available with help of total seed content removal (193 \pm 20 ASTA units), than with medium sorting (180 \pm 18 ASTA units); however, significantly longer shelf-life was not achieved (639-958 days). This confirmed that the products were deprived of useful compounds of seeds, which play important protective role against the oxidative degradation of carotenoids. The paprika seed oil and tocopherol additives decreased the degradation rate of extractable colour, thus improving the estimated shelf-life time up to 1,230 days marginal mean (Figure 6D).

The desirability function approach enabled the inspection of predicted dependent variables at different combinations of levels of independent variables. Figure 7 shows the searching result for the predictor (processing) variables that produce the highest desirability value $(0.986)$. This was available with the following factor settings: high extractable colour of paprika variety, protected post-harvest ripening, slow drying and milling intensity $(330 \mathrm{~kg} / \mathrm{h}$ and $110 \mathrm{~kg} / \mathrm{h})$, medium seed content $(10.5 \%)$ and supplementation with spice paprika seed oil (6\%) and tocopherol extract $(0.2 \%)$. The predicted values of rate constant of accelerated storage-stability test and shelf-life time were -0.494 ASTA units/day and 2,326 days, respectively. The predicted shelf-life extremely exceeded the preliminary goal of the present study (two years). This meant an opportunity for modified factor level settings that resulted in lower desirability values, but enabled taking into account some important expectations or practical considerations.

Table 2 shows some alternative factor level settings with satisfactory dependent variables, meanwhile the intensity of processing was increased and the tocopherol additive was omitted. The processing was repeated with No. 1, 2 and 3 settings, using 2018 season's spice paprika crop. The observed shelf-life values (with their 95\% confidence intervals) were 926 days (894-958 days), 772 days (745-798 days) and 631 days (610-653 days) for No 1, 2 and 3 settings, respectively. These results showed that the real observed values 
TABLE 2. Desirability function-based prediction of colour degradation rate constant and shelf-life of spice paprika powder products, based on alternative factor-level settings.

\begin{tabular}{|c|c|c|c|c|c|c|c|c|c|c|}
\hline No. & $\begin{array}{l}\text { Variety } \\
\left(\mathrm{x}_{1}\right)\end{array}$ & $\begin{array}{l}\text { Post-harvest } \\
\text { ripening } \\
\left(\mathrm{x}_{2}\right)\end{array}$ & $\begin{array}{c}\text { Drying } \\
\left(\mathrm{x}_{3}\right)\end{array}$ & $\begin{array}{c}\text { Seed } \\
\text { content } \\
\left(\mathrm{x}_{4}\right) \\
\end{array}$ & $\begin{array}{l}\text { Milling } \\
\left(\mathrm{x}_{5}\right)\end{array}$ & $\begin{array}{c}\text { Paprika } \\
\text { seed oil } \\
\left(\mathrm{x}_{6}\right) \\
\end{array}$ & $\begin{array}{l}\text { Tocopherol } \\
\text { additive } \\
\left(\mathrm{x}_{7}\right) \\
\end{array}$ & $\begin{array}{l}\text { Desirability } \\
\text { (D) }\end{array}$ & $\begin{array}{c}\mathrm{k} \\
(\text { ASTA units/day)* }\end{array}$ & $\begin{array}{l}\theta_{\mathrm{s}[100 \mathrm{ASTA}]} \\
\left(_{\text {days })^{*}}\right.\end{array}$ \\
\hline 0. & Mihalyteleki & Protected & $\begin{array}{c}\text { Slow } \\
(330 \mathrm{~kg} / \mathrm{h})\end{array}$ & $\begin{array}{l}\text { Medium } \\
(10.5 \%)\end{array}$ & $\begin{array}{c}\text { Slow } \\
(110 \mathrm{~kg} / \mathrm{h})\end{array}$ & $6 \%$ & $0.2 \%$ & 0.986 & $\begin{array}{c}-0.494 \\
(-0.672-0.315)\end{array}$ & $\begin{array}{c}2326 \\
(2267-2385)\end{array}$ \\
\hline 1. & Fesztival & $\begin{array}{l}\text { Outdoors, } \\
\text { heap }\end{array}$ & $\begin{array}{l}\text { Moderate } \\
(416 \mathrm{~kg} / \mathrm{h})\end{array}$ & $\begin{array}{c}\text { Medium } \\
(10.5 \%)\end{array}$ & $\begin{array}{l}\text { Moderate } \\
(140 \mathrm{~kg} / \mathrm{h})\end{array}$ & $3 \%$ & $0.2 \%$ & 0.802 & $\begin{array}{c}-0.972 \\
(-1.069-0.874)\end{array}$ & $\begin{array}{c}918 \\
(885-950)\end{array}$ \\
\hline 2. & Fesztival & $\begin{array}{l}\text { Outdoors, } \\
\text { heap }\end{array}$ & $\begin{array}{l}\text { Moderate } \\
(416 \mathrm{~kg} / \mathrm{h})\end{array}$ & $\begin{array}{c}\text { Medium } \\
(10.5 \%)\end{array}$ & $\begin{array}{l}\text { Moderate } \\
(140 \mathrm{~kg} / \mathrm{h})\end{array}$ & $3 \%$ & $0 \%$ & 0.589 & $\begin{array}{c}-1.420 \\
(-1.518-1.322)\end{array}$ & $\begin{array}{c}712 \\
(680-744)\end{array}$ \\
\hline 3. & Meteorit & $\begin{array}{c}\text { Outdoors, } \\
\text { heap }\end{array}$ & $\begin{array}{l}\text { Moderate } \\
(416 \mathrm{~kg} / \mathrm{h})\end{array}$ & $\begin{array}{c}\text { Medium } \\
(10.5 \%)\end{array}$ & $\begin{array}{l}\text { Moderate } \\
(140 \mathrm{~kg} / \mathrm{h})\end{array}$ & $3 \%$ & $0 \%$ & 0.505 & $\begin{array}{c}-1.381 \\
(-1.489-1.274)\end{array}$ & $\begin{array}{c}617 \\
(581-652)\end{array}$ \\
\hline
\end{tabular}

*Mean and minimum-maximum predicted values. $\mathrm{k}$ - degradation rate constant of extractable colour, $\theta_{\mathrm{s}[100 \mathrm{ASTA}]}$ - estimated shelf-life, calculated for 100 ASTA units.

of dependent variables met the predicted values and their $95 \%$ confidence intervals (Table 2 ).

\section{CONCLUSIONS}

This study demonstrated that the desirability profiler, based on extended set of experimental data, is a useful tool for empirically-based quality improvement in spice paprika processing. The model is suitable to take into account the changing conditions and some important expectations, for example productivity, additive-free requirements etc.

Post-harvest ripening, drying, sorting (seed content modification), milling and additives (paprika seed oil and/or tocopherol extract) were identified as important for the degradation rate constant of extractable colour of paprika powders. Post-harvest ripening is crucial in the biosynthesis of stable carotenoids. The results suggested that different Capsicum varieties have a diversity of post ripening demands (time, light or dark and temperature) to reach the best extractable colour accumulation. The extractable colour stability was very sensitive to the milling and drying intensity, while proper setup of other processing steps (e.g. seed content, supplementation with spice paprika seed oil or tocopherol) can compensate the adverse effect of drying and milling parameters. The study proved that processing steps have an additive impact on the storage stability of extractable colour of spice paprika powder. The presented technology with moderate intensity of processing steps and moderate treatments were found to be appropriate to maintain the achieved extended shelf-life.

The results revealed that the planned fractional factorial experimental design methods, extended to entire processing line, lead to better optimal solution for colour stability improvement than the investigation of some selected processing steps.

\section{RESEARCH FUNDING}

This work was supported by GINOP-2.1.7-15-2016-01670 project at the Rubin Spice Paprika Processing Szeged Ltd. (Hungary, traditional spice paprika production area of Szeged).

\section{CONFLICT OF INTERESTS}

The authors declare that there is no conflict of interest.

\section{ORCID IDs}

H.G. Daood https://orcid.org/0000-0001-6004-7650

L. Helyes https://orcid.org/0000-0001-7365-8653

A. Koncsek https://orcid.org/0000-0001-7532-7401

B.P. Szabó https://orcid.org/0000-0001-5950-3858

\section{REFERENCES}

1. Acedo, A.L. (2010). International cooperator's guide of post -harvest technology for fresh chili pepper in Cambodia, Laos, and Vietnam. International Cooperator's Guide. AVRDC World Vegetable Center, 10-735, 1-6.

2. Arimboor, R., Natarajan, R.B., Menon, K.R., Chandrasekhar, L.P., Moorkoth, V. (2015). Red pepper (Capsicum annuum) carotenoids as a source of natural food colors: Analysis and stability-a review. Journal of Food Science and Technology, 52, 1258-1271.

https://doi.org/10.1007/s13197-014-1260-7

3. ASTA (AMERICAN SPICE TRADE ASSOCIATION) (1997). Extractable colour in capsicums and their oleoresins. Method no. 20.1. Official Analytical Methods of the American Spice Trade Association, 4th ed., pp. 89-104.

4. Berke, T.G., Shieh, S.C. (2001) Capsicum, chillies, paprika, bird's eye chilli. In K.V. Peter (Ed.), Handbook of Herbs and Spices. Published in North and South America by CRC Press LLC, pp. 111-121.

https://doi.org/10.1533/9781855736450.111

5. Chopan, M., Littenberg, B. (2017). The association of hot red chili pepper consumption and mortality: A large population-based cohort study. PLoS ONE, 12(1), art. no. e0169876. https://doi.org/10.1371/journal.pone.0169876

6. Daood, H.G., Kapitany, J., Biacs, P.A., Albrecht, K. (2006). Drying temperature, endogenous antioxidants and capsaicinoids affect carotenoid stability in paprika (red pepper spice). Journal of the Science of Food and Agriculture, 86(14), 2450-2457 https://doi.org/10.1002/jsfa.2639

7. Daood, H.G., Palotás, G., Palotás, G., Somogyi, G., Pék, Z., Helyes, L. (2014). Carotenoid and antioxidant content of ground paprika from indoor-cultivated traditional varieties and new hybrids of spice red peppers. Food Research International, 65, Part B, 231-237.

https://doi.org/10.1016/j.foodres.2014.04.048 
8. Daood, H.G., Vinkler, M., Markus, F., Hebshi, E.A., Biacs, P.A (1996). Antioxidant vitamin content of spice red pepper (paprika) as affected by technological and varietal factors. Food Chemistry, 55(4), 365-372.

\section{https://doi.org/10.1016/0308-8146(95)00136-0}

9. Giuffrida D., Dugo, P., Torre, G., Bignardi, C., Cavazza, A., Corradini, C., Dugo, G. (2013) Characterization of 12 Capsicum varieties by evaluation of their carotenoid profile and pungency determination. Food Chemistry, 140(4), 794-802. https://doi.org/10.1016/j.foodchem.2012.09.060

10. Hamed, M., Kalita, D., Bartolo, M.E., Jayanty, S. (2019). Capsaicinoids, polyphenols and antioxidant activities of Capsicum annuum: Comparative study of the effect of ripening stage and cooking methods. Antioxidants, 8(9), art. no. 364. https://doi.org/10.3390/antiox8090364

11. Ibrahim, H.M.A, Ragab, G.H., Moharram, H.A. (1997). Paprika color quality: Effect of air and natural drying treatments. Grasas y Aceites, 48(4), 200-206.

https://doi.org/10.3989/gya.1997.v48.i4.790

12. İnanç, L.A., Demirci, M., Alpaslan, M. (2010). Effects of vegetable oils on the quality parameters of red pepper during storage. Journal of Tekirdag Agricultural Faculty, 7(1), 39-47.

13. ISO 7540:2006 Ground paprika (Capsicum annuum L.) specification.

14. Karam, M.C., Petit, J., Zimmer, D., Djantou, E.B., Scher, J. (2016). Effects of drying and grinding in production of fruit and vegetable powders: A review. Journal of Food Engineering, $188,32-49$. https://doi.org/10.1016/j.jfoodeng.2016.05.001

15. Koncsek, A., Daood, H.G., Horváth Zs.H., Fekete, M., Véha, A., Helyes, L. (2019). Improvement of antioxidant content and color stability in spice paprika powder by rosemary extract supplementation. Journal of Food Processing and Preservation, 43(8), art. no. 14000 .

https://doi.org/10.1111/jfpp.14000

16. Koncsek, A., Kruppai, L., Helyes, L., Bori, Zs., Daood, H.G. (2016). Storage stability of carotenoids in paprika from conventional, organic and frost-damaged spice red peppers as influenced by illumination and antioxidant supplementation. Journal of Food Processing and Preservation, 40(3), 453-462.

https://doi.org/10.1111/jfpp.12623

17. Márkus, F., Daood, H.G., Kapitany, J., Biacs, P.A. (1999). Change in the carotenoid and antioxidant content of spice red pepper (paprika) as a function of ripening and some technological factors. Journal of Agricultural and Food Chemistry, 47(1), 100-107.

https://doi.org/10.1021/jf980485z

18. Martí, M.C., Camejo, D., Olmos, E., Sandalio, L.M., Fernández- García, N., Jiménez, A., Sevilla, F. (2009). Characterization and changes in the antioxidant system of chloroplasts and chromoplasts isolated from green and mature pepper fruits. Plant Biology, 11(4), 613-624.

https://doi.org/10.1111/j.1438-8677.2008.00149.x

19. Martí, M.C., Camejo, D., Vallejo, F., Romojano, F., Bacarizo, S., Palma, J.M., Sevilla, F., Jiménez, A. (2011). Influence of fruit ripening stage and harvest period on the antioxidant content of sweet pepper cultivars. Plant Foods and Human Nutrition 66, 416-423.

https://doi.org/10.1007/s11130-011-0249-x
20. Montgomery, D.C. (2013). Design and Analysis of Experiments (8th ed.). John Wiley \& Sons, Inc. ISBN 978-1118-14692-7, p. 257.

21. Moór, J., Somogyi, N. (2017). History of spice paprika research in Hungary. In Gyuricza, Cs., Somogyi, N. and Radó G. (Eds.), The Spice Paprika Research in Hungary is 100 Years Old. NAIK, ISBN: 978-615-5784-02-8, 7-16 (in Hungarian).

22. Obermayer, E. (1934). Commodity knowledge of Hungarian Paprika. Reprinted in: Gyuricza, Cs., Somogyi, N., Radó G. (Eds.), (2017), The Spice Paprika Research in Hungary is 100 Years Old. NAIK, ISBN: 978-615-5784-02-8, 29-34 (in Hungarian).

23. Osuna-Garcia, J.A., Wall, M.M., Waddell, C.A. (1997). Natural antioxidants for preventing color loss in stored paprika. Journal of Food Science, 62 (5), 1017-1021.

https://doi.org/10.1111/j.1365-2621.1997.tb15027.x

24. Pal, S., Gauri, S.K. (2018). A desirability functions-based approach for simultaneous optimization of quantitative and ordinal response variables in industrial processes. International Journal of Engineering, Science and Technology, 10(1), 76-87. https://doi.org/10.4314/ijest.v10i1.6

25. Peleg, M., Normand, M.D., Corradini, M.G. (2017). A new look at kinetics in relation to food storage. Annual Review of Food Science and Technology, 8, 1-19.

https://doi.org/10.1146/annurev-food-030216-025915

26. Pérez-Gálvez, A., Garrido-Fernández, J., Mínguez-Mosquera, M.I. (2000). Effect of high-oleic sunflower seed on the carotenoid stability of ground pepper. Journal of Agricultural and Food Chemistry, 77(1), 79-83. https://doi.org/10.1007/s11746-000-0012-x

27. Perez-Galvez, A., Hornero-Mendez, D., Minguez-Mosquera, M.I. (2009). Stability of paprika without supplementary antioxidants during storage under industrial controlled conditions. Journal of Agricultural and Food Chemistry, 57(11), 4718-4723. https://doi.org/10.1021/jf804058m

28. Pola, W., Sugaya, S., Photchanachai, S. (2020). Influence of postharvest temperatures on carotenoid biosynthesis and phytochemicals in mature green chili (Capsicum annuum L.). Antioxidants, 9(3), art. no. 203.

https://doi.org/10.3390/antiox9030203

29. Schieber, A., Carle, R. (2005). Occurrence of carotenoid cis-isomers in food: Technological, analytical, and nutritional implications. Trends in Food Science \& Technology, 16(9), 416-422. https://doi.org/10.1016/j.tifs.2005.03.018

30. Singh, K.K., Goswami, T.K. (1999). Design of a cryogenic grinding system for spices. Journal of Food Engineering, 39(4), 359-368. https://doi.org/10.1016/S0260-8774(98)00172-1

31. Spiller, F., Alves, M.K., Vieria, S., Carvalho, T.A., Leite, C.E., Lunardelli, A., Poloni, J.A., Cunha, F.Q., de Oliveira, J.R. (2008). Anti-inflammatory effects of red pepper (Capsicum baccatum) on carrageenan and antigen-induced inflammation. Journal of Pharmacy and Pharmacology, 60(4), 473-478.

https://doi.org/10.1211/jpp.60.4.0010

32. Szegedipaprika(2010).HU/PDO/0005/0395 [http://ec.europa.eu/ agriculture/quality/door/registeredName.html?denomination $I d=2111]$. Accessed November 10, 2020.

33. Topuz, A., Ozdemir, F. (2003). Influences of $\gamma$-irradiation and storage on the carotenoids of sun-dried and dehydrated paprika. Journal of Agricultural and Food Chemistry, 51 (17), 4972-4977. https://doi.org/10.1021/jf034177z 